\title{
The North Atlantic Oscillation controls air pollution transport to the Arctic
}

\author{
S. Eckhardt ${ }^{1}$, A. Stohl ${ }^{1,4}$, S. Beirle ${ }^{2}$, N. Spichtinger ${ }^{1}$, P. James ${ }^{1}$, C. Forster ${ }^{1}$, C. Junker ${ }^{3}$, T. Wagner ${ }^{2}$, U. Platt ${ }^{2}$, and \\ S. G. Jennings ${ }^{3}$ \\ ${ }^{1}$ Department of Ecology, Technical University of Munich, Germany \\ ${ }^{2}$ Institute of Environmental Physics, Heidelberg University, Germany \\ ${ }^{3}$ Department of Experimental Physics, National University of Ireland, Ireland \\ ${ }^{4}$ now at Cooperative Institute for Research in Environmental Sciences, University of Colorado/NOAA Aeronomy Laboratory, \\ USA
}

Received: 4 April 2003 - Published in Atmos. Chem. Phys. Discuss.: 24 June 2003

Revised: 29 September 2003 - Accepted: 16 October 2003 - Published: 24 October 2003

\begin{abstract}
This paper studies the interannual variability of pollution pathways from northern hemisphere $(\mathrm{NH})$ continents into the Arctic. Using a 15-year model simulation of the dispersion of passive tracers representative of anthropogenic emissions from $\mathrm{NH}$ continents, we show that the North Atlantic Oscillation (NAO) exerts a strong control on the pollution transport into the Arctic, particularly in winter and spring. For tracer lifetimes of 5 (30) days, surface concentrations in the Arctic winter are enhanced by about $70 \%$ (30\%) during high phases of the NAO (in the following referred to as $\mathrm{NAO}^{+}$) compared to its low phases $\left(\mathrm{NAO}^{-}\right)$. This is mainly due to great differences in the pathways of European pollution during $\mathrm{NAO}^{+}$and $\mathrm{NAO}^{-}$phases, respectively, but reinforced by North American pollution, which is also enhanced in the Arctic during $\mathrm{NAO}^{+}$phases. In contrast, Asian pollution in the Arctic does not significantly depend on the NAO phase. The model results are confirmed using remotely-sensed $\mathrm{NO}_{2}$ vertical atmospheric columns obtained from seven years of satellite measurements, which show enhanced northward $\mathrm{NO}_{2}$ transport and reduced $\mathrm{NO}_{2}$ outflow into the North Atlantic from Central Europe during $\mathrm{NAO}^{+}$phases. Surface measurements of carbon monoxide (CO) and black carbon at high-latitude stations further corroborate the overall picture of enhanced Arctic pollution levels during $\mathrm{NAO}^{+}$phases.
\end{abstract}

Correspondence to: A. Stohl

(astohl@al.noaa.gov)

\section{Introduction}

During winter and spring, the Arctic suffers from high levels of anthropogenic pollution (Mitchell, 1957), leading to decreased visibility - the Arctic haze (Barrie, 1986) - radiative forcing of the Arctic climate (Garrett et al., 2002), soil pollution (Meijer et al., 2003), and accumulation of persistent organic chemicals (Wania, 2003). Accumulation of ozone precursors in the Arctic in winter and their release to lower latitudes in spring also causes a peak in photochemical ozone formation, contributing to the spring-time maximum in photooxidants that is observed throughout much of the northern hemisphere (NH) troposphere (Penkett and Brice, 1986). Factors that cause the winter/spring maximum of Arctic pollution, i.e. seasonal changes in pollutant removal rates, photochemical processes, local meteorology and pollution transport pathways, are reasonably well understood now (Barrie, 1986; Polissar et al., 2001). There is also evidence for downward trends of, e.g., sulfate, cadmium, or aerosols that have been related to emission reductions (Bodhaine, 1989; Li et al., 2003). However, little attention has yet been paid to the influence of climate variability on interannual changes of Arctic air pollution levels.

In the NH, especially during the winter months, the most prominent and recurrent pattern of atmospheric variability is the North Atlantic Oscillation (NAO), a redistribution of atmospheric mass between the Arctic and the subtropical Atlantic (Hurrell, 1995). Oscillations between high and low NAO phases produce large changes in the mean wind speed and direction over the Atlantic, the heat and moisture transport between the Atlantic and the neighbouring continents, and the intensity and number of storms (Hurrell et al., 2003). Thus, NAO-related influences on hemispheric-scale pollution transport are to be expected. Indeed, it has been shown that the NAO influences the transport of Saharan dust into 
Table 1. Winter months and their associated monthly NAO index used for constructing the low and high NAO index ensembles for the 15-year climatology, respectively (indices downloaded on July, 2002)

\begin{tabular}{cccccc}
\hline \multirow{3}{*}{ month } & $\begin{array}{c}\text { low NAO } \\
\text { year }\end{array}$ & index & month & $\begin{array}{c}\text { high NAO } \\
\text { year }\end{array}$ & index \\
\hline 1 & 1987 & -4.6 & 1 & 1983 & 3.5 \\
1 & 1985 & -3.9 & 1 & 1984 & 4.1 \\
1 & 1980 & -2.6 & 1 & 1990 & 4.3 \\
2 & 1986 & -3.9 & 2 & 1992 & 2.7 \\
2 & 1983 & -1.8 & 2 & 1989 & 4.1 \\
2 & 1985 & -1.8 & 2 & 1990 & 4.7 \\
12 & 1989 & -3.8 & 12 & 1986 & 2.7 \\
12 & 1987 & -2.7 & 12 & 1993 & 3.0 \\
12 & 1981 & -2.3 & 12 & 1982 & 3.3 \\
\hline
\end{tabular}

the Atlantic and Mediterranean (Moulin et al., 1997), and photochemical model calculations suggest that it may also modify the transport of pollutants from North America to Europe (Li et al., 2002). Here we present a significant correlation between the NAO and air pollution transport towards the Arctic. The results of this paper represent a strong relationship between the NAO and model results of global pollution transport as well as $\mathrm{CO}$ and $\mathrm{BC}$ concentration measured at high latitude measurement stations and $\mathrm{NO}_{2}$ retrieved using spectral data from the Global Ozone Monitoring Experiment (GOME). According to our results, the NAO exhibits the strongest influence on $\mathrm{NH}$ pollution transport out of a series of popular indices describing climate variability in various regions of the globe (other indices investigated were, e.g., the Southern Oscillation, Pacific-North America pattern, Arctic Oscillation). Thus, we concentrate here on the NAO, but we also briefly discuss the Arctic Oscillation, which is related to the NAO.

\section{Methods}

Poleward transport of air pollution was examined in a 15year (1979-1993) climatology of modelled tracer transport, an extension to a previous one-year study (Stohl et al., 2002). The climatology is based on calculations with the Lagrangian particle dispersion model FLEXPART (Stohl et al., 1998), driven by six-hourly meteorological re-analysis data from the European Centre for Medium-Range Weather Forecasts (ECMWF) (Gibson et al., 1999). FLEXPART treats advection and turbulent diffusion by calculating the trajectories of a multitude of particles. Stochastic fluctuations, obtained by solving Langevin equations (Stohl and Thomson, 1999), are superimposed on the grid-scale winds to represent transport by turbulent eddies. More detailed descriptions of FLEXPART and typical applications can be found in papers by Stohl et al. $(2002,2003)$ and Forster et al. (2001). In order to identify the typical pathways taken by pollution plumes originating from the different continents (and their variations with the NAO), we simulated the transport of three (Asian, European, North American) carbon monoxide (CO) pollution tracers. The model setup was the same as in our previous study (Stohl et al., 2002), but the model was run for 15 years using the meteorological re-analysis data. Emissions were taken from the global EDGAR version 2 inventory (Olivier et al., 1996) with the base year 1990. Attribution of an EDGAR grid cell to a particular continent was done approximately according to the continental boundaries shown on a geographical map, resulting in the emission distribution shown in Fig. 1. For North America, Europe and Asia, 240 000, 230000, and 500000 particles were released per month, respectively. Anthropogenic CO emissions have a distribution similar to the emissions of many other anthropogenic pollutants, and thus are used here also as a proxy for anthropogenic pollution in a general sense.

Particles were quasi-continuously (i.e., every 15 minutes) emitted over the 15 -year period. They were tagged with their release time and followed in the simulation for 50 days. Knowing the particles' release time allowed to bin them into 12 age classes. From this dataset, concentrations were calculated every 15 minutes on a three-dimensional $\left(3^{\circ} \times 5^{\circ}\right.$ (latitude/longitude) and 20 vertical levels up $20 \mathrm{~km}$ ) grid. Monthly averages of these fields are used in this study. Thus, for every month of our simulation, 12 concentration fields, each one consisting of tracer of definite age only (e.g., 0 2 days for the "youngest" age class, and 40-50 days for the "oldest" age class) were available for further analyses. This age-spectrum approach is popular in stratospheric research (Hall and Plumb, 1994) and a thorough theoretical description of this method applied to intercontinental pollution transport has recently been published by Holzer et al. (2003). The age spectra are useful for showing how tracer dispersion looks like in a climate-average, taking short-term variations in transport fully into account.

Chemical species in the atmosphere can be characterized by their lifetime $\tau$, after which their mass has decreased to $1 / \mathrm{e}$ of its initial value (i.e., the mass emitted). To determine the concentration $C_{\tau}$ of a species with lifetime $\tau$ from the discrete age spectra, we can use

$$
\left|C_{\tau}\right| \approx \sum_{n=1}^{N} C_{n} e^{-\frac{t_{n}}{\tau}},
$$

where $C_{n}$ is the tracer concentration in the age class $n, t_{n}$ is the mean age of class $n$, and $N$ is the number of age classes used (12 in our case). This approximate relationship holds for species with lifetimes well within the range of the age classes available, i.e. not for species with very short or very long lifetimes.

The age spectra can also be used conveniently to create movies (each consisting of $N$ frames) of time-mean tracer dispersion. This can be done either for an individual month 
a) North American Emissions

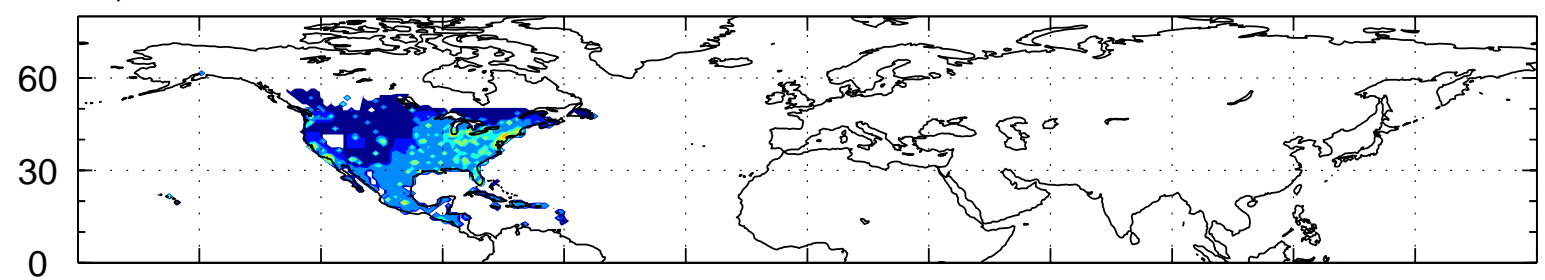

b) European Emissions

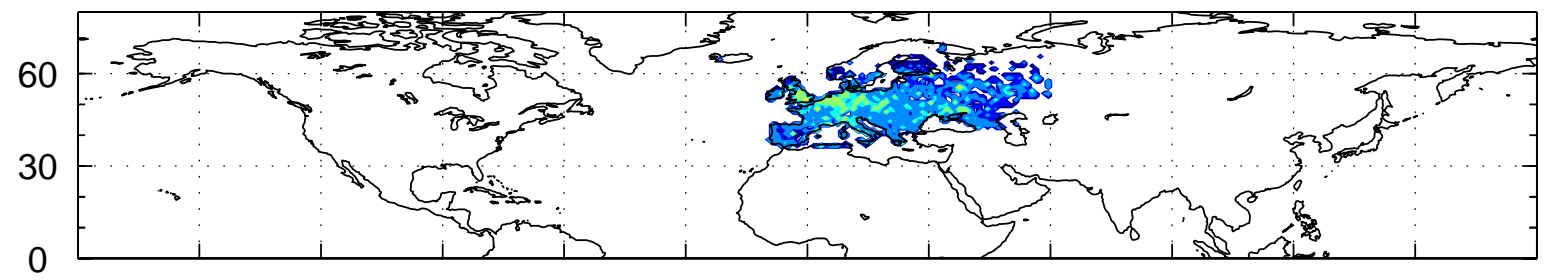

c) Asian Emissions

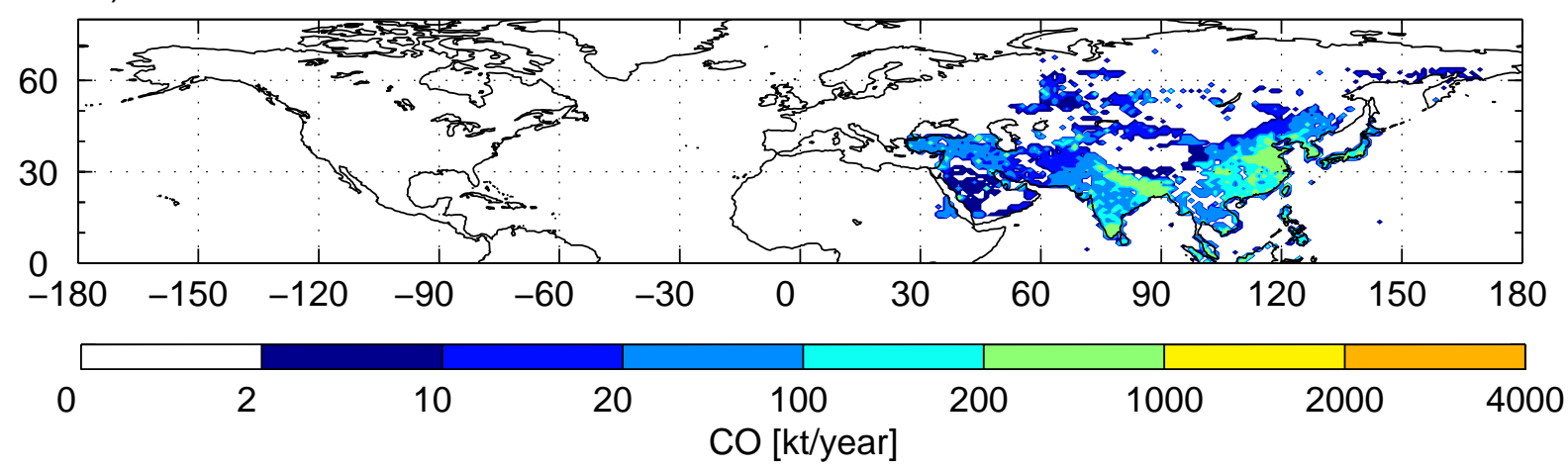

Fig. 1. Anthropogenic CO emissions in kilotons CO per year and $1^{\circ} \times 1^{\circ}$ grid cell according to the EDGAR inventory for the base year 1990 for North America (a), Europe (b) and Asia (c).

(note that we have monthly model output), or for ensembles averaged over months with similar properties (e.g., high NAO indices). These averaged fields are furtheron referred to as composites. To obtain the composites, the age spectra of the months pertaining to the ensemble are averaged.

In order to study the NAO's influence on tracer transport, we have produced composite movies representing ensemble averages of the winter months with the highest (hereafter referred to as $\mathrm{NAO}^{+}$) and lowest $\left(\mathrm{NAO}^{-}\right) 20 \%$ of all NAO indices. The mean values of these ensembles are 3.6 and -3.0 , respectively. Table 1 gives detailed information on the months and indices used to create the $\mathrm{NAO}^{+}$and $\mathrm{NAO}^{-}$composites. The NAO index used here was calculated from the difference of sea level pressure (SLP) between Ponta Delgada, Azores and Stykkisholmur/Reykjavik, Iceland normalized with the standard deviation in SLP for each station (Hurrell, 1995).In wintertime the NAO index explains $33 \%$ of the total variance of the SLP field over the Atlantic (Hurrell and v. Loon , 1997). The monthly NAO index values were taken from an internet website (http://www. cgd.ucar.edu/ $\sim$ jhurrell/nao.html). This website was updated since we downloaded the data, and the recent values have changed slightly from those that we have used here. However, the changes are small and, as we have checked, do not affect our results noticeably. A correlation and linear regression analysis between tracer concentration and the NAO index was performed for every individual model grid cell, such that the spatial distribution of the correlations and regressions could be shown. This is a standard technique used in climatology (e.g. Hurrell et al., 2003).

\section{Results}

Figure 2 shows snapshots from the two dispersion movies of the European tracer for composites based on months with $\mathrm{NAO}^{+}$conditions and months with $\mathrm{NAO}^{-}$conditions, respectively. The full movies showing the dispersion of the European, Asian and North American tracers are available from the internet website http://www.forst.tu-muenchen.de/ EXT/LST/METEO/arcticpollution. After 2-4 days (Fig. 2a and $\mathrm{b}$ ), the European pollution plume is largely confined to south of $60^{\circ} \mathrm{N}$ for $\mathrm{NAO}^{-}$, but it reaches $70^{\circ} \mathrm{N}$ for $\mathrm{NAO}^{+}$. 
a) $\mathrm{NAO}^{-}$, Age: 2-4 days

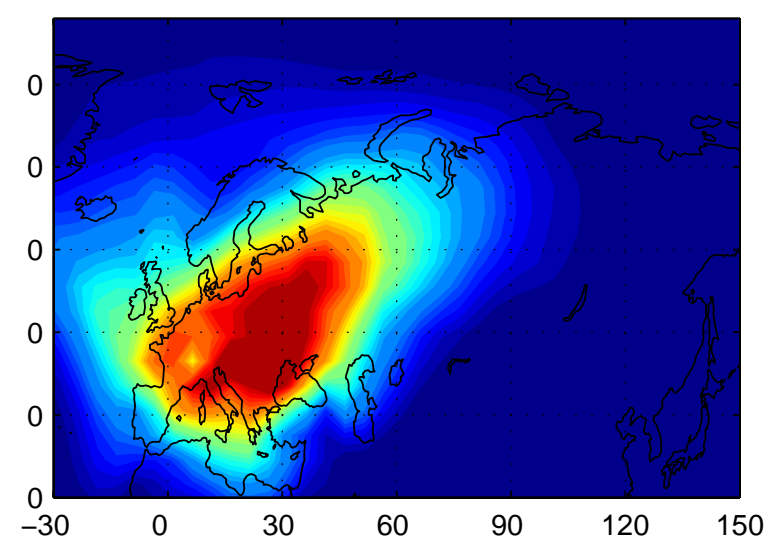

b) $\mathrm{NAO}^{+}$, Age: 2-4 days

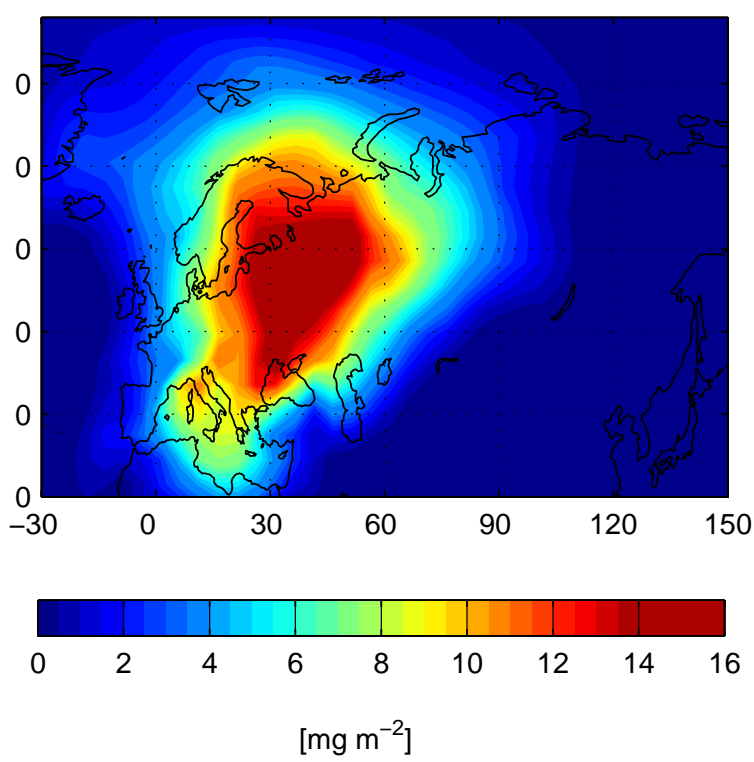

c) $\mathrm{NAO}^{-}$, Age: 8-10 days

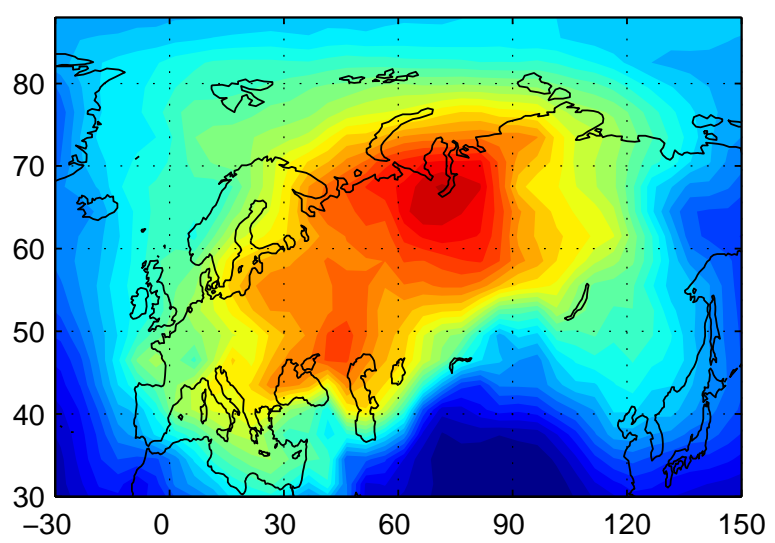

d) $\mathrm{NAO}^{+}$, Age: 8-10 days

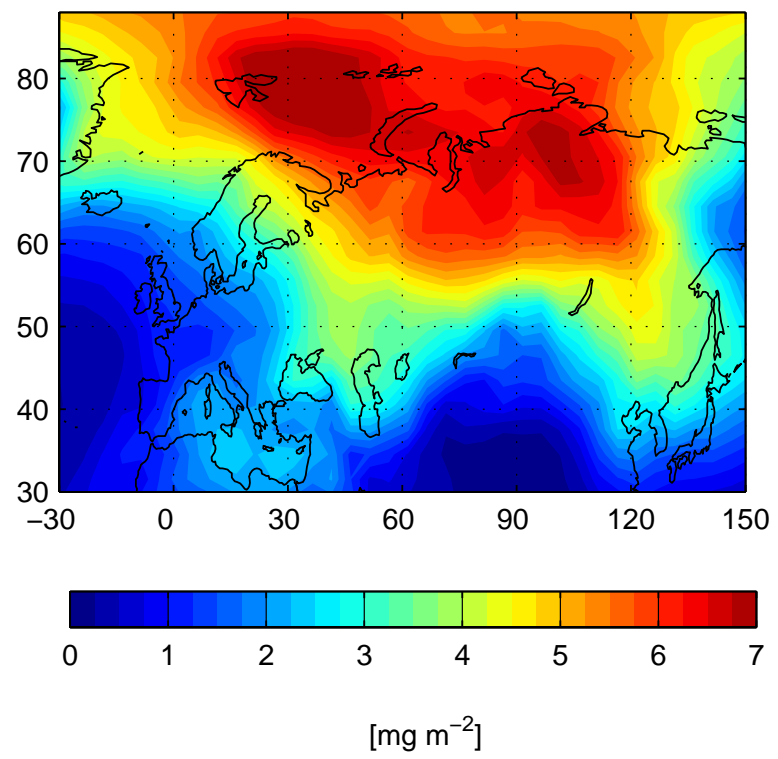

Fig. 2. European tracer columns $\left[\mathrm{mg} \mathrm{m}^{-2}\right]$ 2-4 days $(\mathbf{a}, \mathbf{b})$, and 8-10 days $(\mathbf{c}, \mathbf{d})$ after tracer emission. The two composites represent the three December, January and February months with the lowest and highest NAO index, respectively, selected from a 15-year (1979-1993) period.

After 8-10 days (Figs. 2c and d), most of the European tracer is found south (north) of the Arctic circle for the $\mathrm{NAO}^{-}$ $\left(\mathrm{NAO}^{+}\right)$composites. In the movies, large differences between the two NAO phases are evident for up to 25 days, after which the differences decrease. Thus, while European pollution is eventually transported to the Arctic under both regimes, the poleward transport is faster during $\mathrm{NAO}^{+}$ phases.

Figure 3 shows the corresponding plots for the North America tracer. Like for the European tracer, more North American tracer reaches Arctic latitudes during $\mathrm{NAO}^{+}$ phases, even though the differences between the $\mathrm{NAO}^{+}$and $\mathrm{NAO}^{-}$are smaller. The tracer's transport across the North
Atlantic is faster and directed towards higher latitudes for the $\mathrm{NAO}^{+}$ensemble. Transport of North American air pollution is strongly affected by the warm conveyor belt airstreams of extratropical cyclones (Stohl et al., 2002), and these warm conveyor belts show a similar correlation with the NAO (Eckhardt et al., 2003).

In order to quantify the contributions of European, Asian and North American emissions to the Arctic pollution, we plot for both NAO phases the average tracer mixing ratios at the surface, averaged over the Arctic region north of $70^{\circ} \mathrm{N}$, in dependence of the tracer's e-folding lifetime. Fig. 4 reveals three important facts: Firstly, European emissions contribute more to Arctic pollution than Asian and North American 
a) $\mathrm{NAO}^{-}$, Age: $2-4$ days

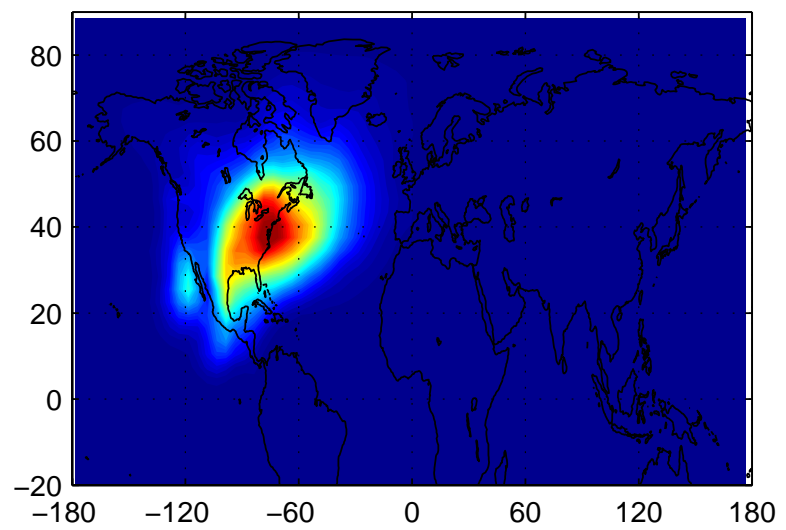

b) $\mathrm{NAO}^{+}$, Age: $2-4$ days
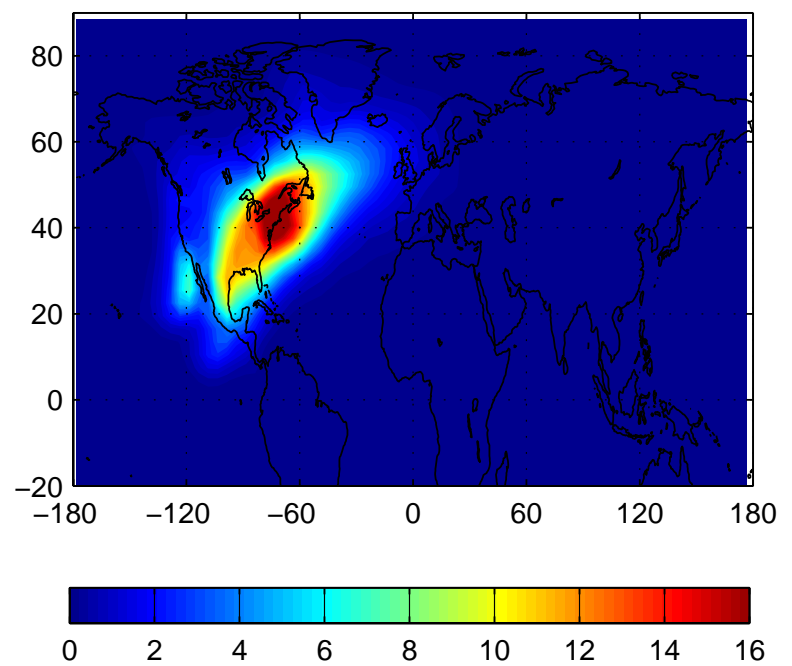

$\left[\mathrm{mg} \mathrm{m}^{-2}\right]$

Fig. 3. Same as Fig. 2, but for the North American tracer.

emissions together, due to Europe's position at higher latitudes and prevailing airflow patterns (Stohl et al., 2002). Secondly, more tracer from all three source continents is found in the Arctic for $\mathrm{NAO}^{+}$than for $\mathrm{NAO}^{-}$. Thirdly, the NAO dependence is strongest for the European tracer and decreases with its e-folding lifetime, as can be seen by the relative differences between $\mathrm{NAO}^{+}$and $\mathrm{NAO}^{-}$being greatest for the European tracer and at the shortest lifetimes. For an e-folding lifetime of 5 days (30 days), 90\% (50\%) more European tracer and $70 \%$ (30\%) more tracer in total resides in the Arctic for $\mathrm{NAO}^{+}$than for $\mathrm{NAO}^{-}$.

Figure 5 shows maps of the slopes between the surface mixing ratios of the 30-day-lifetime tracers (from all $\mathrm{NH}$ continents together, as well as from Europe, America, and Asia alone), and the NAO index, obtained from a linear re- c) $\mathrm{NAO}^{-}$, Age: $8-10$ days

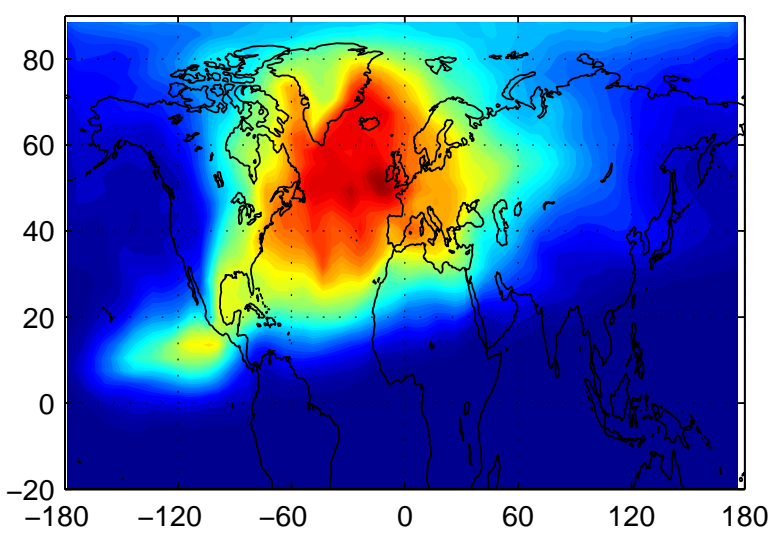

d) $\mathrm{NAO}^{+}$, Age: $8-10$ days

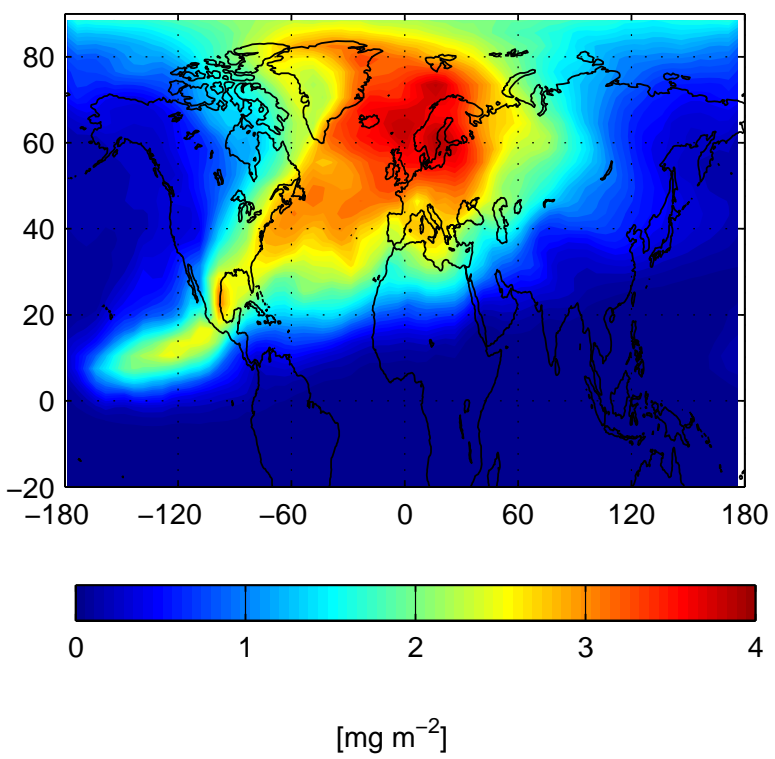

gression model analysis. Furthermore, correlation coefficients are superimposed as white lines, in order to identify those regions where the slopes have been obtained from significant correlation results. Both the North American tracer and the European tracer show a bipole pattern, with a region of positive slopes north of the main source region, and a region with negative slopes south of the source region. These patterns are significant, as can be seen by the correlation coefficients, which show values up to -0.83 and +0.67 (for our sample size a correlation coefficent of \pm 0.37 indicates significance on the $99 \%$ level). The slopes for the Asian tracer reveal a more complicated distribution, which is largely not significant, according to the correlation coefficients. However, in the polar regions, positive slopes are found for the Asian tracer, too. The slopes for tracer mixing 


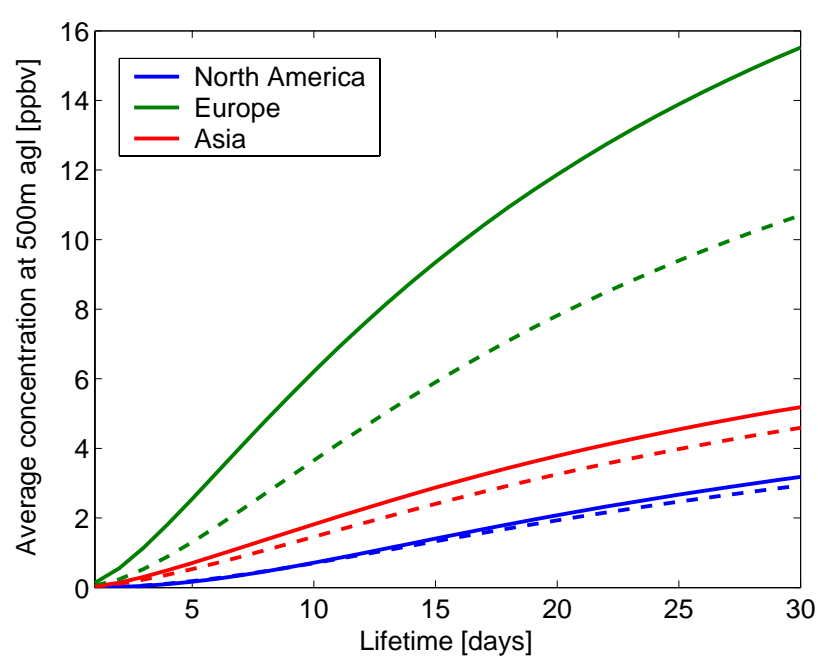

Fig. 4. Dependence of the winter-time mean tracer mixing ratios [ppbv] at the surface, averaged over the region north of $70^{\circ} \mathrm{N}$, on tracer lifetime for $\mathrm{NAO}^{+}$(bold lines) and $\mathrm{NAO}^{-}$(dashed lines) ensembles, respectively, for European (green lines), North American (blue lines) and Asian tracer (red lines).

ratios originating from all $\mathrm{NH}$ continents together closely resemble the results for Europe alone, confirming the dominant European signal. We also performed the same analysis for the Arctic Oscillation (AO) index, which revealed similar patterns. At the lowest level, the main difference for the tracer with 30 days lifetime is that the very high positive correlations over northern Scandinavia disappear when using the AO. However, high positive correlations remain over the entire Arctic area. Positive slopes with significant correlations are also found in the Asian region for the $\mathrm{AO}$, which are not seen with the NAO. The analysis for the AO can be viewed on our website.

To prove that the NAO affects the pollution outflow from Europe as suggested by the model, we use satellite measurements of a short-lived (lifetime of hours in the boundary layer, and up to a few days in the free troposphere) substance, nitrogen dioxide $\left(\mathrm{NO}_{2}\right)$, from GOME. GOME is a spectrometer operating in nadir-viewing geometry on the ERS-2 satellite since 1995 (Burrows et al., 1999). From the spectral data, total column $\mathrm{NO}_{2}$ is retrieved using Differential Optical Absorption Spectroscopy (Leue et al., 2001). Nitrogen oxides have in the troposphere an important role for human health, climate and atmospheric chemistry. They have influence on Ozone production as well as on $\mathrm{OH}$ concentration (Atkinson, 2000; Jacob, 2003). Residual $\mathrm{NO}_{2}$ columns were constructed for $\mathrm{NAO}^{+}$minus $\mathrm{NAO}^{-}$conditions (see Table 1 for the months selected and their NAO indices) in the same manner as for the model results, but using the seven winters with available GOME data. The residuals show a dipole structure with a $\mathrm{NO}_{2}$ surplus over northern Europe and a deficit over western Europe (Fig. 6a). $\mathrm{NO}_{2}$ data are less reliable in regions where clouds are present, and they also reflect patterns in stratospheric $\mathrm{NO}_{2}$. Both cloud patterns and the amount of stratospheric $\mathrm{NO}_{2}$ may vary with the NAO. Stratospheric $\mathrm{NO}_{2}$ may particularly vary because tropopause heights change with the NAO. To rule out that the dipole pattern seen in Fig. 6a could have been produced by one of these mechanisms, careful analyses of cloud data from GOME itself, the International Satellite Cloud Climatology Project (Rossow and Schiffer, 1999), and ECMWF tropopause heights for $\mathrm{NAO}^{+}$and $\mathrm{NAO}^{-}$were done. These analyses showed that neither cloud patterns nor tropopause heights showed residuals that corresponded to the identified spatial structures. Thus, the $\mathrm{NO}_{2}$ residuals are no artifact of the retrieval technique, but really show an enhanced outflow into the Arctic and a decreased outflow into the North Atlantic of European pollution for the $\mathrm{NAO}^{+}$compared to the $\mathrm{NAO}^{-}$ensemble.

A map of $\mathrm{NAO}^{+}$minus $\mathrm{NAO}^{-}$residuals of the European 1-day-lifetime tracer columns (Fig. 6b) corroborates this finding. Even though the time periods of the model simulations and the measurements do not overlap and the model does not account for chemical transformations and deposition (other than applying a 1-day lifetime), there is very good general agreement between the two maps. Note that our youngest age class is actually $0-2$ days, such that the 1day-lifetime tracer cannot be accurately computed, but rather reflects the patterns of the 0-2 days age class. This explains why the dipole structure seen in the model results has a larger dimension than the corresponding $\mathrm{NO}_{2}$ dipole, as $\mathrm{NO}_{x}$ has a lifetime on the order of hours to a day.

The spatial patterns identified in both the GOME observations and the model results are statistically significant, as shown by the correlation coefficients between the NAO index and vertical columns. Correlation coefficients were calculated for the full period of available data (i.e., not only the $\mathrm{NAO}^{+}$or $\mathrm{NAO}^{-}$composites). For the model results, correlation coefficients between the NAO indices and the tracer columns range from -0.79 to 0.68 . For the $\mathrm{NO}_{2}$ observations, the enhanced northward flow for high NAO is also highly significant (correlations up to 0.62 , for our sample size a correlation coefficent of 0.58 is significant on the $99 \%$ level), whereas the reduced outflow to the west is less significant (correlations up to -0.21 ).

Unfortunately, $\mathrm{NO}_{2}$ has too short a lifetime to trace the pollution all the way into the Arctic. However, in-situ measurements of longer-lived substances at high-latitude stations confirm our model results. Table 3 shows results of a linear correlation analysis of $\mathrm{CO}$ data at three Arctic stations (Spitsbergen, Barrow, Alert) and at the Irish west coast (Mace Head), obtained from the NOAA global flask sampling network (Novelli et al., 1998), and black carbon (BC) data (Cooke et al., 1997) at Mace Head. CO and BC have lifetimes of several months and about 10 days, respectively, in the Arctic winter. Since all time series show a downward trend, which is not discussed further here, a multiple linear 
a) Northern Hemisphere

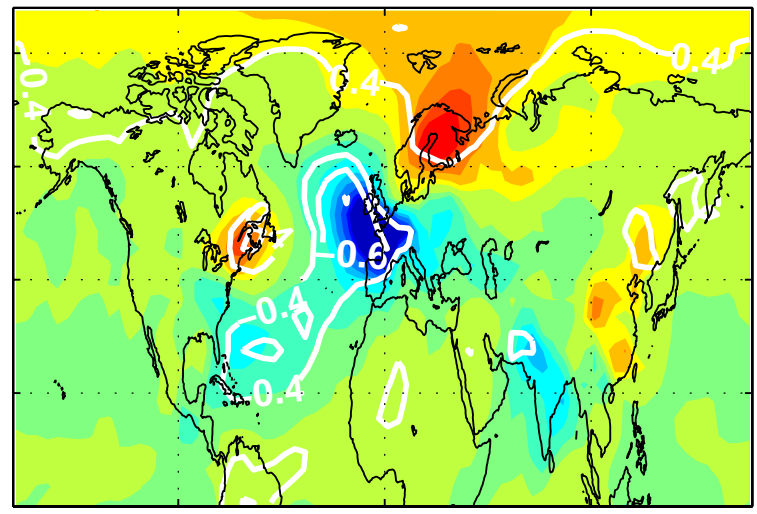

c) Europe

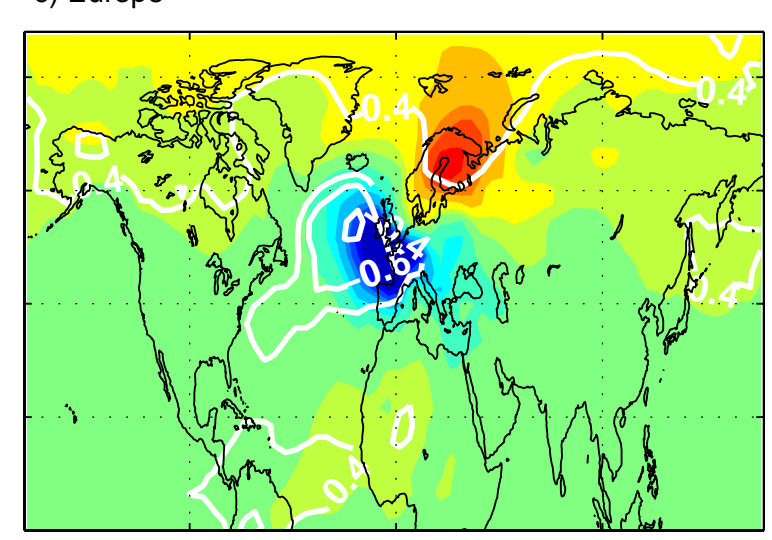

d) Asia

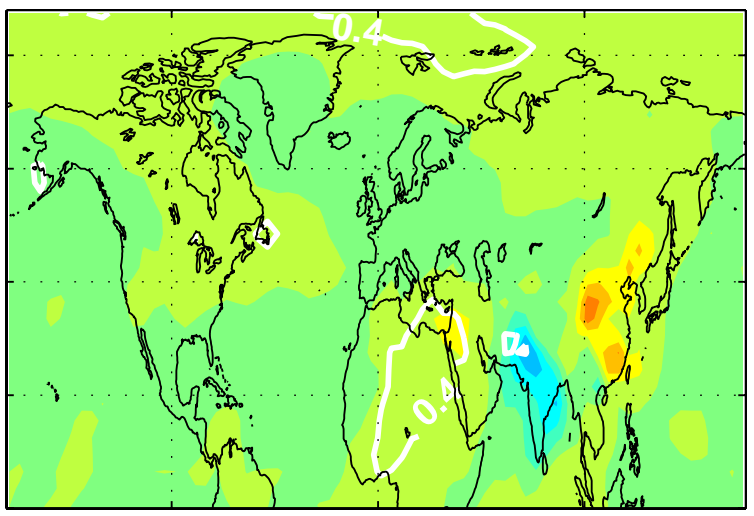

b) North America

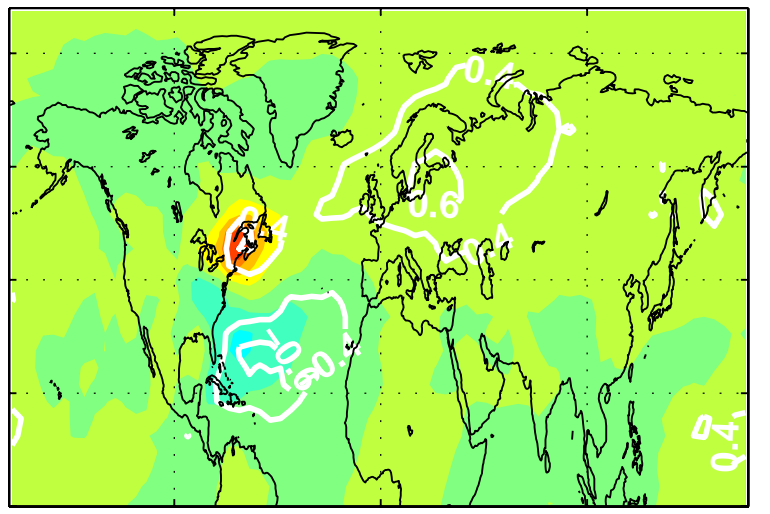

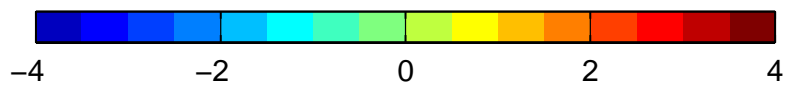

[pbbv]

Fig. 5. Maps of the slopes (ppbv per index unit) between the 30-day-lifetime model tracer, and the NAO index in winter, for (a) all three NH source continents together, (b) North America alone, (c) Europe alone, and (d) Asia alone. The slopes were obtained by carrying out a linear regression analysis with the NAO index as the independent variable, and the tracer mixing ratio in the lowest model layer as the dependent variable. The white contour lines show the correlation coefficient between NAO and the model tracer (contours are drawn at $\pm 0.4, \pm 0.6$ and $\pm 0.8)$.

regression was performed with both time and the NAO index as independent variables, in order to exclude the possibility that correlations are due to joint NAO and emission trends. At all stations the NAO index is the main explanatory variable, and thus a regression with the NAO index alone yields very similar correlations and slopes. Depending on the station, the NAO explains about $30-50 \%$ of the variability seen in the data. At the Irish Mace Head research station, close to the negative pole in Fig. 6, there is a modest negative correlation between $\mathrm{NAO}$ and $\mathrm{CO}$. According to the model simulations, this is a superposition of a strong negative correlation with European $\mathrm{CO}$ and a weaker positive correlation with
North American CO (Fig. 5). For the shorter-lived BC, for which the North American influence is small, we see a very strong and highly significant negative correlation with the NAO, reflecting reduced outflow from Europe to the North Atlantic during $\mathrm{NAO}^{+}$phases, which is due to the generally stronger westerly winds during high NAO phases.

In contrast, highly significant positive correlations between NAO and CO are found at all Arctic stations, confirming the enhanced poleward transport of air pollution from Europe and North America during $\mathrm{NAO}^{+}$phases, seen in Figs. $2-5$. For NAO indices of $-4(+4)$, CO is nearly $10 \%$ lower (higher) than on average. Fig. 5 demonstrates that most 
a) $\mathrm{NO}_{2}$ from GOME

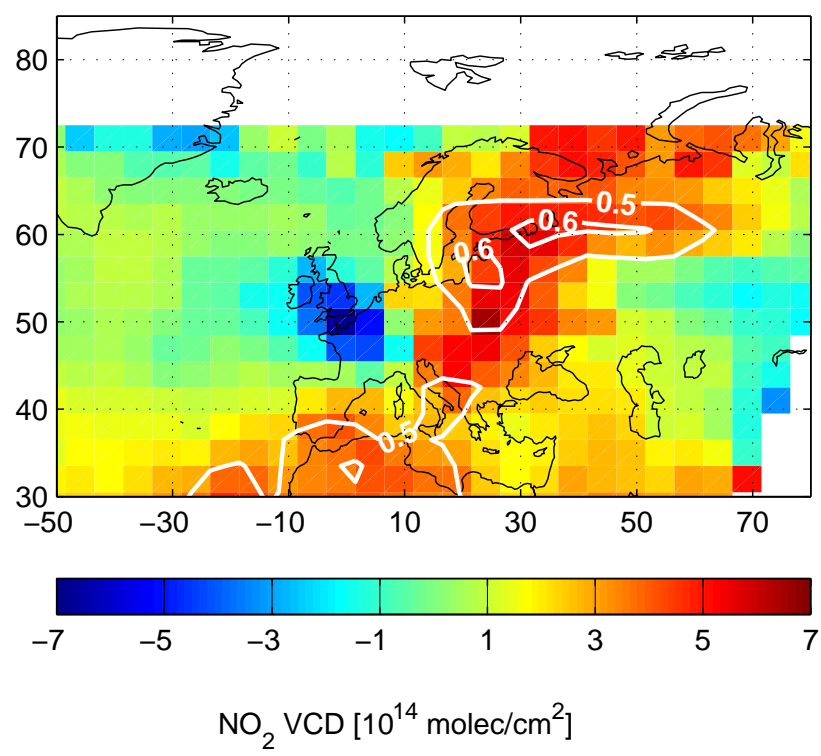

b) FLEXPART Tracer

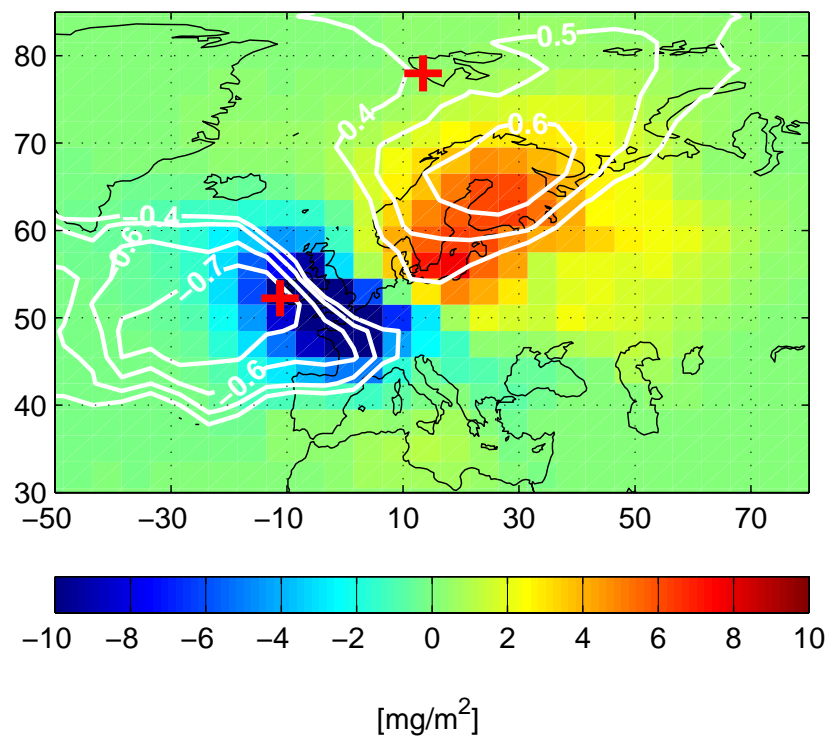

Fig. 6. Comparison of observed and simulated NAO signal in pollution transport from Europe. Map of the residual $\mathrm{NO}_{2}$ vertical columns $\left[10^{14}\right.$ molecules $\left.\mathrm{cm}^{-2}\right]$ retrieved from GOME satellite observations for $\mathrm{NAO}^{+}$minus $\mathrm{NAO}^{-}$composites during seven (1996-2002) winters (a). Residuals of vertical columns of the European 1-day-lifetime tracer during 15 winters (1979-1993) (b). In both (a) and (b), the colours show the tracer column residuals $\left[\mathrm{mg} \mathrm{m}^{-2}\right.$ ]. Superimposed as white lines are the correlation coefficients between the NAO indices and the $\mathrm{NO}_{2}$ columns (in a) or the tracer columns (in b) for the full periods with available data. Crosses mark the locations of measurement sites at Mace Head and Spitsbergen.

Table 2. Winter months and their associated monthly NAO index used for constructing the low and high NAO index ensembles for the GOME $\mathrm{NO}_{2}$, respectively (indices downloaded on August, 2003)

\begin{tabular}{cccccc}
\hline & low NAO & & \multicolumn{3}{c}{ high NAO } \\
month & year & index & month & year & index \\
\hline 12 & 2001 & -4.1 & 1 & 1999 & 1.3 \\
12 & 1996 & -3.7 & 12 & 1998 & 1.6 \\
1 & 1997 & -2.4 & 12 & 1999 & 1.7 \\
12 & 2000 & -2.2 & 2 & 1999 & 2.2 \\
1 & 1996 & -1.8 & 2 & 2000 & 3.1 \\
\hline
\end{tabular}

of this correlation can be explained by NAO-related modifications of European pollution transport.

Similar, albeit weaker, correlations between the NAO and both measurement data and model results were found for spring, whereas for summer and autumn low correlations were obtained. This is expected, as the NAO is strongest in winter and early spring (Hurrell et al., 2003). Similar correlations were found with alternative NAO-related patterns like the Arctic Oscillation (see our supplementary website). The NAO was used here because European emissions are most important for Arctic air pollution and the NAO possesses the greatest explanatory power over the Euro-Atlantic region (Ambaum et al., 2001).

\section{Discussion and conclusions}

Using a 15-year tracer transport climatology based on model simulation driven by ECMWF wind fields it was found in this study that transport of anthropogenic pollution from all three $\mathrm{NH}$ continents correlates with the NAO in winter and spring. Enhanced transport of pollution to the Arctic from all three $\mathrm{NH}$ continents was observed during high NAO phases. The strongest dependency of simulated Arctic pollution levels on the NAO occurred for the pollution originating from $\mathrm{Eu}-$ rope, and the dependence of transport on the NAO index (see Fig. 4) was strongest for tracers with short lifetimes. Satellite observations of $\mathrm{NO}_{2}$ show a similar correlation with the NAO index and, thus, confirm the model results. CO measurements at Arctic surface stations, which are all positively correlated with the NAO, further corroborate our model results.

Our observation that the NAO controls pollution outflow from $\mathrm{NH}$ continents into the Arctic possibly has important consequences. During the past decades, there has been a positive trend in the NAO (Hurrell, 1995), explaining partly why climate change in the Arctic was probably faster than anywhere else in the world (Moritz et al., 2002). Anthropogenic aerosols reduce cloud droplet sizes (Bréon et al., 2002), which globally leads to negative radiative forcing due to an increase in cloud reflectivity. However, under Arctic 
Table 3. Table shows coefficients obtained from a multiple linear regression with $\mathrm{CO}$ or $\mathrm{BC}$ as dependent, and time and NAO index as

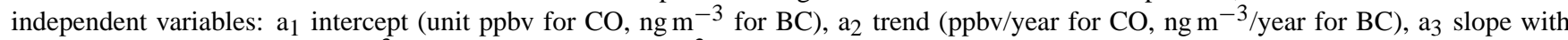
NAO index (ppbv for $\mathrm{CO}, \mathrm{ng} \mathrm{m}^{-3}$ for BC). ${ }^{*}$ significance of $\mathrm{r}^{2}$ on the ${ }^{*} 5 \%$ level, ${ }^{* *} 1 \%$ level, ${ }^{* * *} 0.1 \%$ level.

\begin{tabular}{llllllll}
\hline Station & Location & Period & Species & $\mathrm{r}^{2}$ & $\mathrm{a}_{1}$ & $\mathrm{a}_{2}$ & $\mathrm{a}_{3}$ \\
\hline Mace Head & $53.3^{\circ} \mathrm{N} 9.9^{\circ} \mathrm{W}$ & $1991-2001$ & $\mathrm{CO}$ & $0.27^{*}$ & 192 & -4.2 & -4.4 \\
Mace Head & $53.3^{\circ} \mathrm{N} 9.9^{\circ} \mathrm{W}$ & $1989-2001$ & $\mathrm{BC}$ & $0.49^{* * *}$ & 180 & -3.1 & -31.7 \\
Spitsbergen & $78.9^{\circ} \mathrm{N} 11.9^{\circ} \mathrm{E}$ & $1994-2001$ & $\mathrm{CO}$ & $0.41^{* *}$ & 170 & -0.9 & 3.3 \\
Barrow & $71.3^{\circ} \mathrm{N} 156.6^{\circ} \mathrm{W}$ & $1994-2001$ & $\mathrm{CO}$ & $0.44^{* * *}$ & 186 & -2.4 & 4.0 \\
Alert & $82.5^{\circ} \mathrm{N} 62.5^{\circ} \mathrm{W}$ & $1994-2001$ & $\mathrm{CO}$ & $0.28^{* *}$ & 187 & -2.7 & 2.8 \\
\hline
\end{tabular}

conditions (large solar zenith angles, high surface albedo because of snow and ice), increased cloud reflectivity does not lead to surface cooling, because of the absence of short-wave radiation. Instead, aerosols and thin clouds warm the surface by increasing the longwave emissivity (Garrett et al., 2002), which adds to the forcing by greenhouse gases. Thus, part of the observed Arctic warming may have been due to enhanced transport of anthropogenic pollution into the Arctic during the past decades, both because of increasing emissions and the positive NAO trend. Very recently, though, the Arctic has cooled and become less cloudy in winter (Wang and Key, 2003), which could be related to recent emission reductions in Europe and North America, while the NAO has stabilised in the last decade. This hypothesis is speculative at the moment, but it could be tested by doing sensitivity runs with climate models, in which aerosol formation from highlatitude regions are switched on and off, respectively.

Another implication of our results is a possible feedback on the NAO itself, caused by transport of short-lived greenhouse gases (e.g., ozone) and aerosols to the Arctic varying with the NAO phase. Both the strength and the direction of such a feedback loop are unknown yet, but if it exists it could be highly relevant. This hypothesis could be explored by looking how the NAO develops with and without emissions from high-latitude regions in chemistry-climate models.

According to our results, the NAO may lead to large interannual and decadal variability of nitrogen deposition to the Arctic Ocean, with potentially important ecological implications (Pearl et al., 1999) and feedbacks on climate through the uptake of carbon dioxide. Furthermore, a negative correlation between the NAO and nitrate concentrations in U.K. freshwaters has been reported, but is not yet explained (Monteith et al., 2000). We suggest that variability in atmospheric transport of nitrogen from the European mainland and the U.K. itself is responsible.

Acknowledgements. This study was funded by the German Federal Ministry for Education and Research within the Atmospheric Research Program 2000 (AFO 2000) as part of the projects CARLOTTA and NOXTRAM. ECMWF and the German Weather Service permitted access to the ECMWF archives. We acknowledge the National Oceanic and Atmospheric Administration (NOAA), Climate Monitoring and Diagnostics Laboratory (CMDL), Carbon
Cycle Group, for providing CO data on the web, and J. Hurrell from the Climate Analysis Section, NCAR, Boulder, USA, for the NAO index data. Support of the BC measurement programme by T. Gerard Spain at Mace Head is gratefully acknowledged. We also wish to acknowledge support from the EU through the 5FP Project: CORE (Climate-Biosphere-Interactions), Contract number: EVRICT1999-40009. Finally we would like to thank for the very constructive help of two anonymous reviewers.

\section{References}

Ambaum, M. H. P., Hoskins, B. J., and Stephenson, D. B., Arctic Oscillation or North Atlantic Oscillation?, J. Climate, 14, 34953507, 2001.

Atkinson, R.: Atmospheric chemistry of VOCs and $\mathrm{NO}_{x}$, Atmos. Environ., 34, 2063-2101, 2000.

Barrie, L. A.: Arctic air-pollution - an overview of current knowledge, Atmos. Environ., 20, 643-663, 1986.

Bodhaine, B. A.: Barrow surface aerosol: 1976-1987, Atmos. Environ., 23, 2357-2369, 1989.

Bréon, F.-M., Tanré, D., and Generoso, S.: Aerosol effect on cloud droplet size monitored from satellite, Science, 295, 834-838, 2002.

Burrows, J. P., Weber, M., Buchwitz, M., Rozanov, V. V., Ladstätter-Weißenmayer, A., Richter, A., DeBeek, R., Hoogen, R., Bramstedt, K., and Eichmann, K. U.: The Global Ozone Monitoring Experiment (GOME): Mission concept and first scientific results, J. Atmos. Sci., 56, 151-175, 1999.

Cooke, W. F., Jennings, S. G., and Spain, T. G.: Black carbon measurements at Mace Head, 1989-1996, J. Geophys. Res., 102, 25 339-25 346, 1997.

Eckhardt, S., Stohl, A., Wernli, H., James, P., Forster, C., and Spichtiner, N.: A 15-year climatology of warm conveyor belts, J. Climate, in press, 2003.

Forster, C., Wandinger, U., Wotawa, G., James, P., Mattis, I., Althausen, D., Simmonds, P., O'Doherty, S., Kleefeld, C., Jennings, S. G., Schneider, J., Trickl, T., Kreipl, S., Jäger, H., and Stohl, A.: Transport of boreal forest fire emissions from Canada to Europe, J. Geophys. Res., 106, 22 887-22 906, 2001.

Garrett, T. J., Radke, L. F., and Hobbs, P. V.: Aerosol effects on cloud emissivity and surface longwave heating in the Arctic, J Atmos. Sci., 59, 769-778, 2002.

Gibson, J. K., Kallberg, P., Uppala, S., Hernandez, A., Nomura, A., and Serrano, E.: ECMWF Re-Analysis Project Report Series, 1. ERA-15 Description, Version 2, ECMWF, Reading, UK, 1999. 
Hall, T. M. and Plumb, R. A.: Age as a diagnostic of stratospheric transport, J. Geophys. Res., 99, 1059-1070, 1994.

Holzer, M., McKendry, I. G., and Jaffe, D. A.: Springtime transPacific atmospheric transport from East Asia: A transit-timePDF approach, J. Geophys. Res., in press, 2003.

Hurrell, J. W., Kushnir, Y., Ottersen, G., and Visbeck, M. (Eds): The North Atlantic Oscillation: Climate Significance and Environmental Impact, Geophysical Monograph Series, 134, 279 pp., 2003.

Hurrell, J. W. and v. Loon, H.: Decadal variations in climate associated with the North Atlantic Oscillation, Clim. Change, 36, 301-326, 1997.

Hurrell, J. W.: Decadal trends in the North Atlantic Oscillation: Regional temperatures and precipitation, Science, 269, 676-679, 1995.

Jacob, D. J.: The oxidizing power of the atmosphere, Handbook of Weather, Climate and Water, edited by Potter, T. D. and Colman, B., Wiley, 2003.

Leue, C., Wenig, M., Wagner, T., Klimm, O., Platt, U., and Jähne, B.: Quantitative analysis of $\mathrm{NO}_{\mathrm{x}}$ emissions from Global Ozone Monitoring Experiment satellite image sequences, J. Geophys. Res., 106, 5493-5505, 2001.

Li, Q., Jacob, D. J., Bey, I., Palmer, P. I., Duncan, B. N., Field, B. D., Martin, R. V., Fiore, A. M., Yantosca, R. M., Parrish, D. D., Simmonds, P. G., and Oltmans, S. J.: Transatlantic transport of pollution and its effects on surface ozone in Europe and North America, J. Geophys. Res. 107, doi: 10.1029/2001JD001422, 2002.

Li, C., Cornett, J., and Ungar, K.: Long-term decrease of cadmium concentrations in the Canadian Arctic air, Geophys. Res. Lett., 30, 1256, doi: 10.1029/2002GL016723, 2003.

Meijer, S. N., Ockenden, W. A., Sweetman, A., Breivik, K., Grimalt, J. O., and Jones, K. C.: Global distribution and budget of PCBs and HCB in background surface soils: implications for sources and environmental processes, Environ. Sci. Technol., 37, 667-672, 2003.

Mitchell, J. M.: Visual range in the polar regions with particulate reference to the Alaskan Arctic, J. Atmos. Terr. Phys. Special Suppl., 195-211, 1957.

Monteith, D. T., Evans, C. D., and Reynolds, B.: Are temporal variations in the nitrate content of UK upland freshwaters linked to the North Atlantic Oscillation?, Hydrol. Process. 14, 1745-1749, 2000.

Moritz, R. E., Bitz, C. M., and Steig, E. J.: Dynamics of recent climate change in the Arctic, Science, 297, 1497-1502, 2002.

Moulin, D., Lambert, C. E., Dulac, F., and Dayan, U.: Control of atmospheric export of dust from North Africa by the North Atlantic Oscillation, Nature, 387, 691-694, 1997.
Novelli, P. C., Masarie, K. A., and Lang, P. M.: Distributions and recent changes of carbon monoxide in the lower troposphere, J. Geophys. Res., 103, 19015-19033, 1998.

Olivier, J. G. J., Bouwman, A. F., Van der Maas, C. W. M., Berdowski, J. J. M., Veldt, C., Bloos, J. P. J., Visschedijk, A. J. H., Zandveld, P. Y. J., and Haverlag, J. L.: Description of EDGAR Version 2.0. A set of global emission inventories of greenhouse gases and ozone depleting substances for all anthropogenic and most natural sources per country basis and on $1^{\circ} \times 1^{\circ}$ grid, RIVM/TNO report, December 1996, RIVM Bilthoven, RIVM report nr. 771060002 [TNO MEP report nr. R96/119], 1996.

Pearl, H. W. and Whitall, D. R.: Anthropogenically-derived atmospheric nitrogen deposition, marine eutrophication and harmful algal bloom expansion: is there a link?, Ambio, 28, 307-311, 1999.

Penkett, S. A. and Brice, K. A.: The spring maximum in photooxidants in the Northern Hemisphere troposphere, Nature, 319, 655-657, 1986.

Polissar, A., Hopke, P. K., and Harris, J. M.: Source regions for atmospheric aerosol measured at Barrow, Alaska. Environ. Sci. Technol., 35, 4214-4226, 2001.

Rossow, W. B. and Schiffer, R. A.: Advances in understanding clouds from ISCCP. Bull. Am. Met. Soc., 80, 2261-2287, 1999.

Stohl, A., Forster, C., Eckhardt, S., Spichtinger, N., Huntrieser, H., Heland, J., Schlager, H., Wilhelm, S., Arnold, F., and Cooper, O.: A backward modeling study of intercontinental pollution transport using aircraft measurements, J. Geophys. Res., 108, 4370, doi: 10.1029/2002JD002862, 2003.

Stohl, A., Eckhardt, S., Forster, C., James, P., and Spichtinger, N.: On the pathways and timescales of intercontinental air pollution transport, J. Geophys. Res., 107, 4684, doi: 10.1029/2001JD001396, 2002a.

Stohl, A. and Thomson, D. J.: A density correction for Lagrangian particle dispersion models, Boundary-Layer Meteorol., 90, 155$167,1999$.

Stohl, A., Hittenberger, M., and Wotawa, G.: Validation of the Lagrangian particle dispersion model FLEXPART against large scale tracer experiment data, Atmos. Environ., 32, 4245-4264, 1998.

Wang, X. and Key, J. R.: Recent trends in Arctic surface, cloud, and radiation properties from space, Science, 299, 1725-1728, 2003.

Wania, F.: Assessing the potential of persistent organic chemicals for long-range transport and accumulation in polar regions, Environ. Sci. Technol., 37, 1344-1351, 2003. 